\title{
Diversity of Beetle (Coleoptera) at Different Crop Ages of Oil Palm at Felda Tekam Pahang, Malaysia
}

\author{
Izfa Riza H. ${ }^{1}$, Nur Atirah, $\mathrm{H}^{2}$., Idris, A. B ${ }^{3}$ and Ahmad Bukhary, A. K ${ }^{4}$
}

\begin{abstract}
The study on the diversity of Coleoptera has been conducted at Felda Tekam, Jengka, Pahang between five consecutive months which were from June 2013 until October 2013. The aim of this study was to investigate the diversity of Coleoptera according to different plots. Each plot indicates different age of planting. There were Plot 1 ( 1 year old or replanting), Plot 2 (3 years old), Plot 3 (6 years old), Plot 4 (18 years old) and Plot 5 (23 years old). A total of 3532 individuals of beetles representing 22 families, 31 subfamilies, 7 species and 25 morpho species were recorded in this study. Family Nitidulidae was the most diverse beetles recorded here, with 1587 individuals while Hydrophilidae was the least diverse beetle recorded with one individual only. The Shannon - Weiner diversity index $\left(\mathrm{H}^{\prime}\right)$ was highest at Plot 2 (3 years old trees) with a value of 2.32. The Evenness Index (E') was highest at Plot 1 (1 year old trees or replanting) with a value of 0.74 , while Margalef's Richness Index (R') was highest at Plot 2 (3 years old trees) with a value of 3.62. There was no significant difference $(\mathrm{F}=0.76, \mathrm{df}=4, \mathrm{p}>0.05)$ between diversity of beetle and the plots (age of planting). Subfamily Erotylinae was recorded as the indicator species in Plot 3 (6 years old trees) which indicate value of $\mathrm{p}<0.05$.
\end{abstract}

Keywords - Coleoptera, diversity, abundance, Felda Tekam.

\section{INTRODUCTION}

$\mathrm{G}$ ENERALLY, insect is one of the components that play a major role in biological diversity. This is due to its ability to respond quickly towards any changes in ecosystems. Therefore, insect is known as a biological indicator for the ecosystems. Beetle was chosen in this study since it was the most diverse insects group and plays a major role in the food chain. Cole et al. [1] said that the beetles are very sensitive to human activities. Therefore, a study about the relationship between the Coleoptera species with different plots considering different age of plant is very crucial. Coleoptera

Izfa Riza Hazmi ${ }^{1}$,Centre for Insect Systematics, School of Environmental and Natural Resource Sciences, Faculty of Science and Technology, Universiti Kebangsaan Malaysia, 43600 Bangi, Selangor, Malaysia.

Nur Atirah Hasmi ${ }^{2}$,Centre for Insect Systematics, School of Environmental and Natural Resource Sciences, Faculty of Science and Technology, Universiti Kebangsaan Malaysia, 43600 Bangi, Selangor, Malaysia.

Idris Abd Ghani ${ }^{3}$,Centre for Insect Systematics, School of Environmental and Natural Resource Sciences, Faculty of Science and Technology, Universiti Kebangsaan Malaysia, 43600 Bangi, Selangor, Malaysia.

Ahmad Bukhary Ahmad Khair ${ }^{4}$,Centre for Insect Systematics, School of Environmental and Natural Resource Sciences, Faculty of Science and Technology, Universiti Kebangsaan Malaysia, 43600 Bangi, Selangor, Malaysia. is the most abundant species in this world with more than 350,000 species were recorded. The commonly found Coleoptera are from Family Coccinellidae, Elateridae, Scarabaeidae and Lampyridae. These beetles live around the world except in Antartic region [2]. Oil palm (Elaeis guineensis) industry in Malaysia has been developed nowadays. Elaeidobius kamerunicus (Coleoptera: Curculionidae) is one of the beneficial insects that play a major role in oil palm pollination [3]. The identification of beneficial insects is important for natural pest control in Integrated Pest Management [4]. Pest control has become the major challengers in oil palm management. IPM is one of the best methods for controlling pest by using biological pest information like an interaction between pests with their environment which is then combined with available pest control methods for managing the pest activities. The proper method for pest management is very important in oil palm plantations since pest and disease control is one of the major factors influencing the crop productions.

\section{MATERIAL AND METHODS}

Sampling activities of the Coleoptera at the Felda Tekam, Jengka Pahang were conducted within five consecutive months which were from June 2013 until October 2013. The traps used in this study were malaise trap, pitfall trap and pitlight trap. The specimens collected were sorted, oven-dried, pinned, identified, labeled and classified in the laboratory at the Centre for Insect Systematics, Universiti Kebangsaan Malaysia (CIS-UKM). All the samples were identified up to species level. All the identified specimens were kept in the CIS-UKM repository for future references.

All the data were then analyzed by Shannon Diversity Index (H'), Evenness Index (E') and Richness Index (R') by using PAST software.

\section{Results AND DisCUSSION}

A total of 3532 individuals of beetles with 22 families, 31 subfamilies, 7 species and 25 morpho species have been recorded in this study (Table 1). Nitidulidae was the most abundant family with 1587 individuals recorded followed by Coccinellidae with 393 individuals, Curculionidae with 332 individuals, Erotylidae with 316 individuals, Mordellidae 
with 140 individuals, Cantharidae with 132 individuals, Carabidae with 122 individuals, Cicindelidae with 84 individuals, Anthribidae with 74 individuals, Chrysomelidae with 70 individuals, Scarabaeidae with 63 individuals, Endomychidae with 48 individuals, Curcujidae with 45 individuals, Staphylinidae with 30 individuals, Haliplidae with 28 individuals, Dytiscidae with 27 individuals, Elateridae with 17 individuals, Tenebrionidae with 11 individuals, Anthicidae with 6 individuals, Derodontidae with 4 individuals, Cerambycidae with 2 individuals and Hydrophilidae is the least abundant family with only one individual recorded here. Three subfamilies which were Carpophilinae, Nitidulinae, Cybocephalinae in which Subfamily Carpophilinae was the most abundant subfamily has been recorded in this study. It was due to the beetles in this subfamily which also known as saproxylic, referring to organisms that feed on decaying organic plants. While, certain beetles in this subfamily known as fungivore that feed on fungi. Plot 3 and plot 4 have many decaying fronds which can attract the Carpophilinae to live there. Most of the sap beetles attracted to tree injuries because they feed on the sap and liquid from this type of trees. However, behavior of Nitidulidae was varying. Sap beetles can be found on variety of habitat which feed on flowers, fruits, sap, fungi, decaying plant tissue and dead animal tissue [5].

Table 2 showed the value of Shannon-Wiener Diversity Index (H'), Evenness Index (E') and Margalef's Richness Index ( $\left.\mathrm{R}^{\prime}\right)$. Based on the table, the diversity of Coleoptera for five different plots were almost similar. Plot 2 has the highest H' value which was 2.32 followed by Plot 1 with $2.30 \mathrm{H}$ ' value, Plot 5 with 2.12 H' value, Plot 3 with $2.03 \mathrm{H}$ ' value and Plot 4 with 1.76 H' value. The highest E' value was Plot 1 with 0.74 followed by Plot 2 with 0.73 , plot 5 with 0.70 , Plot 3 with 0.65 and Plot 4 with 0.56 . The highest R' value was Plot 2 with 3.62 followed by Plot 1 with 3.59 , Plot 4 with 3.27, Plot 5 with 3.19 and Plot 3 with 3.09.

Two-way ANOVA analysis proved that the relationship between abundance of beetles and the plot have no significant difference $(\mathrm{F}=0.76, \mathrm{~d} . \mathrm{k}=4, \mathrm{p}>0.05)$. There was no significant difference for the diversity of Coleoptera because of the ecology itself, microhabitat and their food sources. Plot 1 was the replanting plots that have different plant composition in which it was still not contaminated with fungi and decaying fronds. Unlike Plot 1, Plot 5 consisted of 23 years old plants have a lot of decaying fronds which promotes the existence of Coleoptera habitat. Besides, Plot 1 was well-maintained by insecticide spraying program. Therefore, there was only a small number of Coleoptera existed at this plot.

Herbivorous beetles like Nitidulidae, Cantharidae, Chrysomelidae, Cerambycidae, Coccinelidae, Curculionidae, Elateridae, Mordellidae and Scarabidae formed a large group in this study because they feed on liquid sap from the oil palm plants. Many Erotylidae and Nitidulidae have been found in Plot 4 and Plot 5 which were 18 years old and 25 years old respectively. There were having almost all mossy ground due to the thick canopy, thus it received low intensity of light at the surface of the soil resulting in a high moisture level of the soil. High diversity of Coleoptera in this period of study can be attributed to the existence of an abundance of food [6].

\section{CONCLUSION}

A total of 3532 individuals of Coleoptera with 22 families, 31 subfamilies, 7 species and 25 morpho species have been collected in this study. Nitidulidae was the most dominant family recorded here. The number of species and individuals recorded along this study was according to the different plots indicating the different ages of oil palm plants. However, there was no significant difference between number of Coleoptera and the plot. The plant itself can be the factor that differentiate the diversity and abundance of Coleoptera in the oil palm plantation. There was a contradiction in every study about this Coleoptera. However, it can be concluded that the diversity of Coleoptera in this study was still high.

\section{ACKNOWLEDGMENT}

This project is funded by Division of Higher Education, Malaysian Ministry of Education (MOE) under Exploratory Research Grant Scheme (ERGS), ERGS/1/2013/STWN03/UKM/03/1.

\section{REFERENCES}

[1] Cole, L.J., McCracken, D.I., Dennis, P., Downie, I.S., Griffin, A.L., Foster, G.N., Murphy, K.J., Waterhouse, T. 2002. Relationships between Agricultural Management and Ecological Groups of Ground Beetles (Coleoptera: Carabidae) on Scottish Farmland. Agriculture, Ecosystem, and Environment 93: 323-336. http://dx.doi.org/10.1016/S0167-8809(01)00333-4

[2] Terry, L.E. 1982. Tropical Forests: Their Richness in Coleoptera snd Other Arthropod Species. The Coleopterists Bulletin 36(1):74-75.

[3] Genty, P., Garzón, A., Luchini, F., Delvare, G. 1986. Polinización Entomófila de la Palma Aceitera en América Tropical. Oléagineux 41(3): $99-112$.

[4] Salmah, M. 2005. Study on Taxonomy and Effect of Host Larval Stages and Diets on Development, Parasitism Behavior, Longevity and Fecundity of Apanteles metesae Nixon. UKM.

[5] Parsons, C.T. 1943. A Revision of Nearctic Nitidulidae (Coleoptera). Bulletin of Comparative Zoology 92:121-248.

[6] Huston, M.A. 1996. Biological Diversity. The Coexistence of Species on Changing Landscapes. Cambridge, Cambridge University Press, p. 681. 
TABLE I

Number Of BeEtles In FAmily, SubFAmily AND MorPho SPECIES Were ColleCted From Five DifFerent Plots

\begin{tabular}{|c|c|c|c|c|c|c|c|c|}
\hline Family & Subfamily & $\begin{array}{l}\text { Species/ } \\
\text { Morphospecies }\end{array}$ & $\begin{array}{c}\text { Plot } \\
1\end{array}$ & $\begin{array}{c}\text { Plot } \\
2\end{array}$ & $\begin{array}{c}\text { Plot } \\
3\end{array}$ & $\begin{array}{c}\text { Plot } \\
4\end{array}$ & $\begin{array}{c}\text { Plot } \\
5\end{array}$ & $\Sigma$ \\
\hline \multirow[t]{3}{*}{ Nitidulidae } & Carpophilinae & Carp sp1 & 62 & 51 & 520 & 476 & 195 & 1304 \\
\hline & Nitidulinae & Niti sp1 & 65 & 113 & 15 & 54 & 31 & 278 \\
\hline & Cybocephalinae & Cybo sp1 & 0 & 0 & 0 & 0 & 5 & 5 \\
\hline Cerambycidae & Cerambycinae & Cera sp1 & 0 & 0 & 0 & 1 & 1 & 2 \\
\hline Scarabaeidae & Scarabinae & Scar sp1 & 8 & 7 & 12 & 6 & 30 & 63 \\
\hline Anthribidae & Anthribinae & Antr sp1 & 0 & 46 & 9 & 10 & 9 & 74 \\
\hline \multirow{2}{*}{ Curculionidae } & Scolytinae & Scol sp1 & 24 & 56 & 86 & 35 & 101 & 302 \\
\hline & Curculioninae & Elaeidobius kamerunicus & 4 & 0 & 5 & 18 & 3 & 30 \\
\hline Cucujidae & Cucujinae & Cucujus sp. & 15 & 5 & 13 & 7 & 5 & 45 \\
\hline Dytiscidae & Hydroporinae & Hydr sp1 & 10 & 1 & 9 & 6 & 1 & 27 \\
\hline Elateridae & Elaterinae & Elat sp1 & 0 & 1 & 2 & 5 & 9 & 17 \\
\hline Anthicidae & Anthicinae & Antc sp1 & 2 & 1 & 3 & 0 & 0 & 6 \\
\hline Endomychidae & Endomychinae & Endo sp1 & 0 & 7 & 25 & 6 & 10 & 48 \\
\hline Erotylidae & Erotylinae & Erot sp1 & 11 & 10 & 194 & 51 & 50 & 316 \\
\hline \multirow[t]{2}{*}{ Carabidae } & Trechinae & Trec sp1 & 5 & 20 & 87 & 4 & 2 & 118 \\
\hline & Paussinae & Paussus sp. & 0 & 0 & 2 & 0 & 2 & 4 \\
\hline \multirow[t]{5}{*}{ Chrysomelidae } & Alticinae & Alti sp1 & 1 & 8 & 7 & 4 & 0 & 20 \\
\hline & Cassidinae & Cass sp1 & 0 & 0 & 0 & 2 & 0 & 2 \\
\hline & Chrysomelinae & Chry sp1 & 1 & 0 & 9 & 0 & 2 & 12 \\
\hline & Hispinae & Hisp sp1 & 1 & 2 & 9 & 0 & 0 & 12 \\
\hline & Galerucinae & Gale sp1 & 1 & 23 & 0 & 0 & 0 & 24 \\
\hline Hydrophilidae & Hydrophilinae & Hydro sp1 & 0 & 1 & 0 & 0 & 0 & 1 \\
\hline Staphylinidae & Paederinae & Paed sp1 & 4 & 3 & 17 & 6 & 0 & 30 \\
\hline Mordellidae & Mordellinae & Mord sp1 & 6 & 11 & 48 & 56 & 19 & 140 \\
\hline Derodontidae & Derodontinae & Derodontus sp. & 1 & 1 & 0 & 2 & 0 & 4 \\
\hline \multirow[t]{2}{*}{ Tenebrionidae } & Stenochiinae & Sten sp1 & 5 & 0 & 0 & 1 & 4 & 10 \\
\hline & Lagriinae & Lagr sp1 & 1 & 0 & 0 & 0 & 0 & 1 \\
\hline Cantharidae & Cantharinae & Cant sp1 & 87 & 1 & 20 & 11 & 13 & 132 \\
\hline Haliplidae & Haliplinae & Haliplus sp. & 0 & 2 & 2 & 15 & 9 & 28 \\
\hline \multirow[t]{2}{*}{ Cicindelidae } & Cicindelinae & Cicindela sp. & 12 & 12 & 11 & 6 & 0 & 41 \\
\hline & Cicindelinae & Collyris sp. & 0 & 43 & 0 & 0 & 0 & 43 \\
\hline Coccinellidae & Scymninae & Scym sp1 & 22 & 152 & 144 & 49 & 26 & 393 \\
\hline \multicolumn{2}{|c|}{ Total Individual } & & 348 & 577 & 1249 & 831 & 527 & 3532 \\
\hline \multicolumn{2}{|c|}{ No. of Family } & 22 & 16 & 20 & 18 & 20 & 17 & \\
\hline \multicolumn{2}{|c|}{ No. of Subfamily } & 31 & 22 & 23 & 23 & 23 & 21 & \\
\hline \multicolumn{2}{|c|}{ No. of Morphospesies } & 32 & 22 & 24 & 23 & 23 & 21 & \\
\hline
\end{tabular}

TABLE II

VALUE OF SHANNON - WiENER Diversity INDEX (H'), EVENNESS INDEX (E') AND MARGALEF's RichNESS (R').

\begin{tabular}{|c|c|c|c|c|c|}
\hline \multirow[t]{2}{*}{ Index value } & \multicolumn{5}{|c|}{ Plot } \\
\hline & 1 & 2 & 3 & 4 & 5 \\
\hline H' & 2.30 & 2.32 & 2.03 & 1.76 & 2.12 \\
\hline $\mathbf{E}^{\prime}$ & 0.74 & 0.73 & 0.65 & 0.56 & 0.70 \\
\hline $\mathbf{R}^{\prime}$ & 3.59 & 3.62 & 3.09 & 3.27 & 3.19 \\
\hline
\end{tabular}

